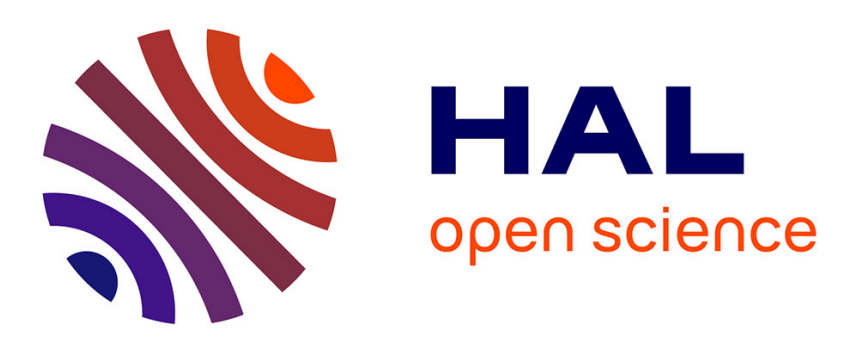

\title{
Metal wires should not be abandoned inside implantable cardioverter-defibrillators leads during heart transplantation!
}

\author{
Laurent Bonnemains, Therese Barbier, Jacques Felblinger
}

\section{To cite this version:}

Laurent Bonnemains, Therese Barbier, Jacques Felblinger. Metal wires should not be abandoned inside implantable cardioverter-defibrillators leads during heart transplantation!. Transplant International, 2016, 29, pp.1136-1138. 10.1111/tri.12803 . hal-03225451

\section{HAL Id: hal-03225451 \\ https://hal.univ-lorraine.fr/hal-03225451}

Submitted on 20 May 2021

HAL is a multi-disciplinary open access archive for the deposit and dissemination of scientific research documents, whether they are published or not. The documents may come from teaching and research institutions in France or abroad, or from public or private research centers.
L'archive ouverte pluridisciplinaire HAL, est destinée au dépôt et à la diffusion de documents scientifiques de niveau recherche, publiés ou non, émanant des établissements d'enseignement et de recherche français ou étrangers, des laboratoires publics ou privés. 


\title{
Metal wires should not be abandoned inside implantable cardioverter-defibrillators leads during heart transplantation!
}

\author{
Laurent Bonnemains ${ }^{1,2,3}$, Therese Barbier ${ }^{1,4}$ \& Jacques Felblinger ${ }^{1,5,6}$
}

\author{
1 INSERM, IADI U947, Nancy, France \\ 2 Department of cardiothoracic surgery, CHU Strasbourg, \\ Strasbourg, France \\ 3 University of Strasbourg, Strasbourg, France \\ 4 Axon'Cable, Montmirail, France \\ 5 University of Lorraine, IADI, Nancy, France \\ 6 CHU Nancy, CICIT 1433, Nancy, France \\ E-mail: laurent.bonnemains@inserm.fr
}

\section{Dear Editors,}

Magnetic resonance imaging (MRI) compatibility is sometimes claimed by manufacturers for implantable cardioverter-defibrillators (ICDs) associated with specific leads. However, these leads are sometimes difficult to retrieve during heart transplantation and may be sectioned and abandoned [1]. Power sheaths can be used to cut the attachment between leads and vessels, with certain unavoidable risks [2]. However, these techniques are time-consuming whereas heart transplantations are rarely planned surgeries and generally occur in addition to whole programmes. The scientific literature states that MRI procedures can induce significant heating in normal leads [3-5]. Langman et al. [3] showed that abandoned leads presented a higher risk than device-attached leads during a cardiac MR exam. However, the situation of an abandoned and truncated ICD lead without any active ICD generator has yet to be addressed.

Typical ICD leads are constituted of several wires aligned within a single insulation frame with a multiluminal design [6]: two low-voltage wires connected to the ventricle for the bipolar sensing/pacing tip and one or two high-voltage wires to conduct the defibrillation energy to the coils. There are a number of possible technical designs: some wires may be shared or paired. One wire (the cathode) is usually shaped as a spiral with a central lumen for stylet passage. In recent years, ICD leads have been manufactured to contain three to seven wires, although typical leads have three or four wires as shown in Fig. 1 (right). MRI uses high energy radio frequency (RF) pulses to transmit energy to protons inside the patient's body. MR compatibility generally requires that the RF is emitted by the body coil. Part of the RF energy is thereafter re-emitted and forms the MRI signal which can be transformed into images. The total amount of energy transmitted to the patient is calibrated during the prescan, based on patient weight and RF conductivity, such that it remains below the threshold of accepted specific absorption rate (SAR). This process is designed to warrant an elevation of body temperature $\leq 0.1{ }^{\circ} \mathrm{C}$ when no conducting materials such as wires are present. The conducting wires can act as RF antennas and thus concentrate the RF energy on the surface of the wires. Theoretically, the optimal efficiency of a single wire acting as an antenna is reached when its length is a multiple of $\lambda / 2$, which is close to $20 \mathrm{~cm}$ at $1.5 \mathrm{~T}$ and $10 \mathrm{~cm}$ at $3 \mathrm{~T}$, inside a human body.

We tested two different ICD leads: (i) the Biotronik(C) Linox Smart ProMRI SD 65/15 (Biotronik, Berlin, Germany) and (ii) the Sorin(C) Isoline 2CR6 (Sorin, Milan, Italy). The former is labelled 'MRI conditional' in combination with an appropriate generator. According to the manufacturer, this label means that MRI scans can be performed only if the lead is connected to its appropriate generator (therefore not abandoned), only with the body coil, and only if there is a clear indication after a risk/benefit analysis, because of remaining residual risk [7]. In the present test, the leads were sectioned at their two ends and left uncapped. On the generator side, they were cut at the retaining ring level. On the heart side, the leads were cut at three different lengths to mimic an abandoned lead during transplantation. A specific phantom designed to measure heating during MRI acquisition was used according to the American Society for Testing Materials standard [8]. The phantom was filled with saline gel, as shown in Fig. 1 (left). Temperature was measured using Neoptix (Neoptix, Quebec City, Canada) fibre optic probes with a differential accuracy of $\pm 0.1{ }^{\circ} \mathrm{C}$. The 


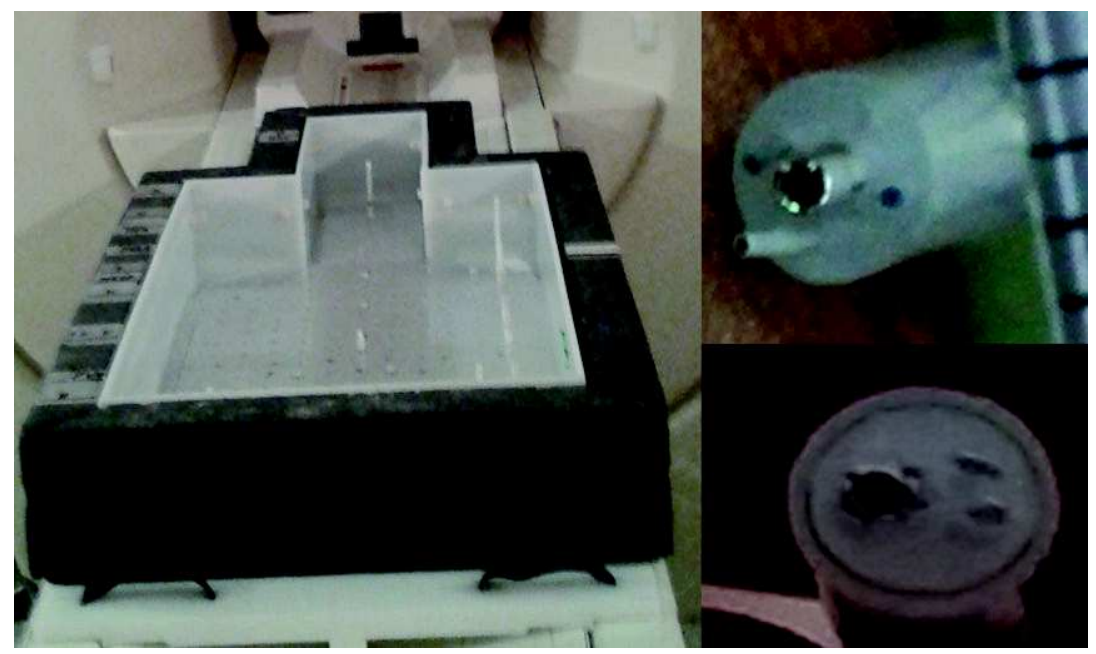

Figure 1 Photograph of the ASTM phantom used for the measurements (Left), and examples of implantable cardioverter-defibrillators leads (Right) with three or four wires (in both cases, the cathode is the big central wire).

temperature was recorded at both ends of the truncated leads during Fast/Turbo Spin Echo sequences, with a mean SAR of $0.39 \mathrm{~W} / \mathrm{kg}$. Such acquisitions are typically used to detect oedema and heart graft rejection $[9,10]$. During the six experiments, an increase in temperature superior to $+5{ }^{\circ} \mathrm{C}$ was observed five times at the heart end and four times at the generator end. During the tests, the highest temperature elevation was $+53.6{ }^{\circ} \mathrm{C}$. Whereas ICD generators are always removed during heart transplantation, surgeons may wonder whether the leads should also be retrieved. Retrieving attached leads can be time-consuming and can, at times, incur complications. It is the intent of this letter to remind the surgical community that very high temperature increases may occur around abandoned ICD leads during MRI examination, especially at high magnetic fields. Indeed, the behaviour of abandoned fragments of ICD leads within the body during MRI examination is quite unpredictable, notably depending on: the structure of the lead (multiluminal leads with several wires), the length of the fragment, the considered end (generator end or heart end), the position of the fragment, the morphology of the patient and consequently, the distance between the body coil (within the bore of the magnet) and the abandoned lead. It is obviously totally unfeasible to analyse all of these parameters simultaneously, all the more so that they clearly interact with each other. For example, body corpulence can modify the distance between the RF emitter and the lead, but also the total RF energy delivered (body weight is used for SAR computation during the prescan) and tissue permittivity (fat and muscle do not have the same permittivity). Therefore, we advocate that when a lead should be abandoned during heart transplantation, surgeons should retrieve the internal wires from the abandoned insulation sheath. In our experience, this procedure is usually simple. For years, leads have been manufactured with a multiluminal model. To ensure both flexibility and resistance to fracture, a decompression space is integrated within the conductor lumens around the wires. To expose the metallic wires, one generally has to simply pinch and pull on the end of the sectioned lead and immediately free the latter, as shown in Video S1. It is then possible to grip the end of the wire with a pincer.

\section{Conflict of interest}

The authors declare no conflict of interest, concerning this letter.

\section{Funding sources}

This study was performed with the help of the PHRC2013 program funded by the French government.

\section{SUPPORTING INFORIMATION}

Additional Supporting Information may be found online in the supporting information tab for this article:

Video S1. Short GIF video (9 Mo) demonstrating how to expose and retrieve the metal wires inside a truncated lead. 


\section{REFERENCES}

1. Buch E, Boyle NG, Belott PH. Pacemaker and Defibrillator Lead Extraction. Circulation 2011; 123: e378.

2. Wilkoff BL, Love CJ, Byrd CL, et al. Transvenous lead extraction: heart Rhythm Society expert consensus on facilities, training, indications, and patient management: this document was endorsed by the American Heart Association (AHA). Heart Rhythm 2009; 6: 1085.

3. Langman DA, Goldberg IB, Finn JP, Ennis DB. Pacemaker lead tip heating in abandoned and pacemaker-attached leads at 1.5 Tesla MRI. J Magn Reson Imaging 2011; 33: 426.

4. Mattei E, Gentili G, Censi F, Triventi M, Calcagnini G. Impact of capped and uncapped abandoned leads on the heating of an MR-conditional pacemaker implant. Magn Reson Med 2015; 73: 390.

5. Helfer JL, Gray RW, MacDonald SG, Bibens TW. Can pacemakers, neurostimulators, leads, or guide wires be MRI safe? Technological concerns and possible resolutions. Minim Invasive Ther Allied Technol 2006; 15: 114

6. Haqqani HM, Mond HG. The implantable cardioverter-defibrillator lead: principles, progress, and promises. Pacing Clin Electrophysiol 2009; 32: 1336.

7. Anon. Biotronik Pro MRI manual. ref: 371712-T.

8. F04 Committee. Test Method for Measurement of Radio Frequency Induced Heating On or Near Passive Implants During Magnetic Resonance Imaging.
West Conshohocken, PA, ASTM International, 2011: www.astm.org; doi: 10.1520/F2182-11A.

9. Bonnemains L, Villemin T, Escanye J-M, et al. Diagnostic and prognostic value of MRI T2 quantification in heart transplant patients. Transpl Int 2014; 27: 69.

10. Bonnemains L, Cherifi A, Girerd N, Odille F, Felblinger J. Design of the DRAGET Study: a multicentre controlled diagnostic study to assess the detection of acute rejection in patients with heart transplant by means of T2 quantification with MRI in comparison to myocardial biopsies. BMJ Open 2015; 5: e008963. 